\title{
Penilaian Proyek dengan Menggunakan Pembiayaan Syariah (Ijarah Muntahiyah Bittamlik)
}

\author{
Mohammad Iqbal Mahardika, I Ketut Gunarta, dan Aang Kunaifi \\ Jurusan Manajemen Bisnis, Fakultas Teknologi Industri, Institut Teknologi Sepuluh Nopember (ITS) \\ Jl. Arief Rahman Hakim, Surabaya 60111 Indonesia \\ e-mail: gunarta@ie.its.ac.id
}

\begin{abstract}
Abstrak-Penilaian usaha adalah kegiatan untuk memperoleh nilai dari suatu objek/perusahaan. Umumnya penilaian usaha dilakukan pada saat perusahaan melakukan strategi ekspansi eksternal. Nilai dari perusahaan dapat berupa penilaian aset tak berwujud, penilaian keuntungan/kerugian ekonomis, dan pembiayaan dari pihak luar yang biasa terjadi pada tahap pengembangan perusahaan. Pembiayaan dari pihak luar perusahaan biasanya dilakukan oleh bank atau lembaga keuangan selain bank. Perbankan di Indonesia menerapkan dual banking system yaitu, konvensional dan syariah. Pada penelitian ini dilakukan penilaian terhadap rencana pengembangan usaha PT. X menggunakan pembiayaan dari bank syariah dengan akad Ijarah Muntahiyah Bittamlik. PT. X memiliki rencana untuk membangun 2 unit PLTU dengan kapasitas masing-masing sebesar 80 MWe. Penilaian dilakukan dari sisi finansial menggunakan pendekatan pendapatan dengan Net Present Value (NPV) sebagai parameter penilaian serta membandingkan nilai Net Present Value (NPV) pembiayaan syariah dengan pembiayaan konvensional. Berdasarkan penelitian yang telah dilakukan diperoleh nilai (Net Present Value) NPV dari proyek dengan pembiayaan syariah sebesar Rp. 445 miliar dan Internal Rate of Return (IRR) sebesar 39,03\%. Nilai Net Present Value (NPV) tersebut diperoleh dengan menggunakan cost of capital sebesar $21 \%$
\end{abstract}

Kata kunci-Ijarah Muntahiyah Bittamlik, Internal Rate of Return, Net Present value, Pembiayaan Syariah, Penilaian Usaha

\section{PENDAHULUAN}

$\mathrm{P}$ ENILAIAN usaha adalah kegiatan untuk memperoleh nilai dari suatu objek atau perusahaan. Peraturan mengenai penilaian usaha di Indonesia diatur dan diawasi oleh Otoritas Jasa Keuangan. Umumnya penilaian usaha dilakukan pada saat perusahaan melakukan strategi ekspansi eksternal. Ekspansi eksternal dilakukan melalui merger maupun akuisisi. Penilaian usaha digunakan untuk menentukan nilai dari perusahaan yang akan diakuisisi maupun merger. Namun menurut Keputusan Ketua Badan Pengawas Pasar Modal dan Lembaga Keuangan Nomor: KEP-372/BL/2012 kegiatan penilaian usaha juga dapat menilai aktivitas perusahaan tersebut, seperti penilaian instrumen keuangan, penilaian aset tak berwujud, pemberian pendapatan kewajaran atas transaksi, penilaian keuntungan atau kerugian ekonomis yang diakibatkan oleh suatu kegiatan atau suatu peristiwa tertentu dan penyusunan studi kelayakan proyek dan usaha.

Dalam era globalisasi ini setiap aktivitas perusahaan perlu dipertimbangkan dan dinilai secara matang. Tingkat persaingan antar persaingan perusahaan menjadi salah satu sebabnya. Salah satunya aktivitas perusahaan yang perlu diperhatikan yaitu pengembangan usaha. Pengembangan usaha memerlukan dana yang cukup banyak sehingga perusahaan perlu mencari tambahan dana di luar dari dana perusahaan.

Pembiayaan dari pihak luar perusahaan biasanya dilakukan oleh bank atau lembaga keuangan selain bank. Indonesia menerapkan dual banking system. Dual banking system adalah dua sistem perbankan (konvensional dan syariah) berjalan secara berdampingan yang diatur dalam peraturan yang berlaku. Sistem ini berlaku sejak Undang-Undang No. 7 tahun 1992 tentang perbankan dan diperbarui dengan UndangUndang No. 10 tahun 1998. Hal yang mendasar yang membedakan antara perbankan konvensional dan syariah adalah terletak pada pengembalian pembagian keuntungan yang diberikan oleh nasabah kepada bank dan yang diberikan oleh bank kepada nasabah.

Undang-undang Nomor 21 tahun 2008 tentang Perbankan Syariah mempertegas eksistensi Perbankan Syariah dan perbedaan dengan sistem perbankan konvensional. Menurut jenisnya, bank syariah terdiri atas Bank Umum Syariah (BUS) dan Bank Pembiayaan Syariah (BPRS). Dalam menjalankan kegiatan usahanya, bank syariah memberikan pembiayaan berdasarkan prinsip bagi hasil (mudharabah), jual-beli barang dengan memperoleh keuntungan (murabahah), akad salam, penyertaan modal (Musharakah), akad istithna, sewa murni tanpa pilihan (ijarah), atau dengan adanya pilihan pemindahan kepemilikan atas barang yang disewa dari pihak bank oleh pihak lain (ijarah wa iqtina), sewa-menyewa yang diakhiri dengan kepemilikan (ijarah muntahiyah bittamlik), dan prinsip lainnya yang tidak bertentangan dengan prinsip syariah.

Pengembangan perbankan dan keuangan syariah lebih bersifat market driven dan dorongan bottom up sehingga lebih bertumpu pada sektor riil menjadi keunggulan tersendiri. Karakteristik khusus lain dimiliki sistem keuangan syariah, yaitu menjaga jarak dengan transaksi spekulatif dan tidak jelas. Selain ini dalam skema syariah tidak diperbolehkan pengenaan bunga (riba), keterlibatan transaksi yang mengandung spekulasi (maysir) dalam setiap transaksi dan adanya unsur ketidakpastian yang tinggi (gharar) dalam transaksi. Karakteristik ini dapat menghindarikan pasar keuangan syariah dari krisis keungan global dan penurunan kegiatan 
perekonomian telah mempengaruhi sebagian besar pasar keuangan global [9]. Hal ini ditunjukan oleh penghimpunan dana perbankan syariah di Indonesia yang selalu mengalami peningkatan selama beberapa tahun terakhir (2012-2015) dari Rp 147,505 triliun pada 2012, Rp 184,122 triliun pada 2013, Rp 199,33 triliun pada 2014 dan Rp 203,894 triliun pada Juni 2015 [7] . Oleh karena itu, sumber pembiayaan yang berasal dari pasar keuangan syariah perlu dipertimbangkan oleh perusahaan dalam meningkatkan keunggulan perusahaan.

Penilaian usaha pada proyek yang menggunakan pembiayaan syariah berbeda dengan penilaian usaha dengan pembiayaan konvensional. Perbedaan tersebut disebabkan oleh adanya perbedaan sistem yang dipakai [5]. Bank syariah menggunakan sistem bagi hasil sedangkan bank konvensional menggunakan sistem bunga. Sistem bunga (riba) dilarang dalam sistem syariah sehingga model pembiayaan dalam perbankan syariah dimodifikasi menjadi sistem sewa menyewa aset. Salah satu kelebihan pembiayaan syariah adalah pembiayaan dengan pendekatan asset-based atau an asset-backed system, di mana setiap kontrak didasarkan pada aset riel atau inventori [9]. Sistem ini tidak akan mempengaruhi likuiditas perusahaan. Selain itu, perusahaan tidak perlu melakukan pemeliharaan aset tersebut.

PT. X merupakan salah satu perusahaan yang memiliki rencana pengembangan usaha. PT. X ingin membuat proyek yang dananya didapatkan dari bank syariah. Proyek tersebut akan menambah nilai dari PT. X, sehingga perlu dilakukan penilaian terhadap rencana pengembangan usaha PT. X pada proyek tersebut.

\section{URAIAN PENELITIAN}

\section{A. Pembiayaan Syariah}

Pengertian pembiayaan syariah menurut Sholihin dalam [3] adalah penyaluran dana dalam bentuk sebagai berikut (a) transaksi bagi hasil dalam bentuk Mudharabah dan Musharakah; (b) transaksi sewa-menyewa dalam bentuk ijarah atau sewa beli dalam bentuk ijarah muntahiyah bittamlik; (c) transaksi jual beli dalam bentuk piutang murabahah, salam dan istish 'na; (d) transaksi pinjam meminjam dalam bentuk piutang Qardh.

Pembiayaan berdasarkan prinsip syariah adalah penyediaan uang atau tagihan yang dipersamakan dengan itu berdasarkan persetujuan atau kesepakatan antara bank dengan pihak lain yang mewajibkan pihak yang dibiayai untuk mengembalikan uang atau tagihan tersebut setelah jangka waktu tertentu dengan imbalan atau bagi hasil (UU Tahun 1998 Tentang Perbankan No. 10 pasal 1 ayat 12 ).

\section{B. Jenis-Jenis Pembiayaan Syariah}

Mudharabah adalah kerjasama usaha antara dua pihak di mana pihak pertama (Shahibul maal) menyediakan seluruh modal, sedangkan pihak lainnya menjadi pengelola. Keuntungan usaha secara Mudharabah dibagi menurut kesepakatan yang dituangkan dalam kontrak, sedangkan rugi ditanggung oleh pemilik modal selam kerugian itu bukan akibat dari kelalaian pengelola. Seandainya kerugian diakibatkan karena kecuarangan atau kelalaian pengelola, maka pengelola harus bertanggungjawab atas kerugian tersebut [3]. Nisbah bagi hasil ditentukan pada saat melakukan perjanjian Mudharabah.

Musharakah adalah kerja sama antara dua pihak atau lebih untuk suatu usaha di mana setiap pihak memberikan kontribusi dana dengan kesepakatan bahwa keuntungan dan risiko akan ditanggung bersama sesuai dengan kesepakatan [1]. Seluruh penyedia modal berhak turut serta dalam manejemen tetapi tidak harus diwajibkan melakukannya. Keuntungan dibagi di antara mitra disepakati dalam rasio tertentu, sedangkan kerugian ditanggung oleh masing-masing sesuai proporsi kontribusi modal masing-masing pihak.

Ijarah ialah akad sewa-menyewa antara pemilik obyek sewa (ma'jur) dan penyewa (musta'jir) agar mendapatkan imbalan atas objek sewa yang disewakan. Ijarah muntahiyah bittamlik adalah akad sewa menyewa antara pemilik objek sewa dan penyewa agar mendapatkan imbalan atas objek yang disewakan dengan opsi perpindahan hak milik objek sewa pada saat tertentu sesuai dengan akad sewa [13].

\section{Standar Akuntansi Ijarah dan Ijarah Muntahiyah Bittamlik}

Standar akuntansi untuk akad ijarah dan ijarah muntahiyah bittamlik (IMBT) yang berlaku di Indonesia adalah PSAK No.107 tentang Akuntansi Ijarah. PSAK No.107 menggantikan standar yang digunakan sebelumnya, yaitu PSAK No.59 tentang akuntansi perbankan syariah. Biaya perolehan, pendapatam dan penyusutan selama masa sewa hanya diakui oleh pemilik obyek sewa. Beban yang diakui oleh pemilik adalah beban biaya perbaikan obyek ijarah. Sedangkan penyewa mencatatkan beban sewa selama masa sewa dan perbaikan jika sudah terjadi perpindahan kepemilikan secara bertahap. Terdapat empat cara perpindahan kepemilikan pada IMBT yaitu hibah, penjualan sebelum masa akah berakhir, penjualan setelah masa akad berakhir dan enjualan secara bertahap.

\section{Pendekatan Pendapatan (Income Based Approach)}

Pendekatan pendapatan adalah memproyeksikan pendapatan ekonomis pada masa mendatang dihubungkan dengan investasinya dan mendiskontokan proyeksi arus pendapatan ke dalam nilai sekarang pada tingkat diskonto yang memadai sesuai dengan risiko yang dihadapi dari prospek arus pendapatan ekonomis [8].

Dalam penelitian ini, pendekatan yang dilakukan adalah pendekatan pendapatan (Income Based Approach). Pendekatan ini bertujuan untuk menentukan nilai pasar wajar dengan cara mengalikan aliran keuntungan yang dihasilkan oleh perusahaan yang bersangkutan dengan tingkat kapitalisasinya (capitalization rate). Tingkat kapitalisasi (capitalization rate) digunakan untuk menentukan present value dari nilai pengembalian yang diharapkan (expected return) dari sebuah bisnis. Pada umumnya, tingkat kapitalisasi didefinisikan sebagai hasil yang diperlukan untuk menarik investor dalam sebuah investasi tertentu dengan mengetahui risiko-risiko yang berkaitan dengan investasi tersebut.

Rata-rata modal tertimbang atau yang bisa dikenal dengan Weighted average cost of capital (WACC) merupakan tingkat 
imbal hasil untuk setiap komponen kapital dinamakan biaya komponen (component cost) dan biaya kapital untuk menganalisa keputusan-keputusan investasi atau capital budgeting. Rumus umum WACC dapat dituliskan sebagai berikut:

$\mathrm{WACC}=\left(\boldsymbol{k}_{e} x W_{e}\right)+\left(k_{d}[\mathbf{1}-t] x W_{d}\right)$

WACC : Weighted Average Cost of capital

$\mathrm{k}_{\mathrm{e}} \quad$ : biaya ekuitas kapital biasa

kd : biaya utang kapital

We : persentase ekuitas kapital dalam susunan kapital

Wd : persentase utang di dalam susunan kapital

t : pajak pendapatan efektif

WACC pada pembiayaan syariah berbeda dengan pembiayaan konvensional. Jika diasumsikan proyek didanai menggunakan 3 tipe pembiayaan syariah mudharabah, musharakah dan ijarah muntahiyah bittamlik maka Weighted average cost of capital (WACC) pada proyek akan menjadi seperti berikut [12]:

$$
W A C C=\frac{M_{1} r_{1}+M_{2} r_{2}+I r_{3}}{V}
$$

WACC : Weighted Average Cost of capital

$\mathrm{M}_{1} \quad$ : proporsi mudharabah

$\mathrm{M}_{2} \quad$ : proporsi musharakah

I : proporsi ijarah muntahiyah bittamlik

$\mathrm{V} \quad$ : total investasi

$\boldsymbol{r}_{\mathbf{1}} \quad$ : biaya mudharabah

$\boldsymbol{r}_{\mathbf{2}} \quad$ : biaya musharakah

$\boldsymbol{r}_{3} \quad$ : biaya ijarah muntahiyah bittamlik

Berikut merupakan rumus menentukan cost of capital pada pembiayaan syariah IMBT menurut [12].

$P=\sum_{t=1}^{T} \frac{L}{(1+y)^{t}}+\frac{E(S)}{(1+y)^{T}}$

$\mathrm{P} \quad$ : Nilai total pembiayaan

$\mathrm{T}$ : Waktu sewa

L : Pembayaran sewa

$\mathrm{y} \quad$ : Cost of capital ijarah muntahiyah bittamlik

$\mathrm{E}(\mathrm{S})$ : Nilai sisa

Net Present Value merupakan metode yang didasarkan pada arus kas yang didiskonto (discounted cash flow). Implementasi dari metode ini adalah dihitung nilai sekarang dari arus kas masuk bersih yang diharapkan dari suatu proyek investasi, didiskontokan dengan biaya modal dan kemudian dikurangi dengan investasi awal. Secara matematik perhitungan NPV dapat dirumuskan sebagai berikut [10]:

$$
N P V=\sum_{n=1}^{n} \frac{F C F}{(1+i)^{n}}-I_{o}
$$

$F C F$ : arus kas bebas (free cash flow)

$i \quad$ : discount rate

$n \quad:$ jumlah periode

$I_{o} \quad$ : investasi awal

Internal Rate of Return (IRR) adalah tingkat bunga yang menyebabkan penerimaan setara dengan arus kas untuk menyamai penyaluran setara dengan arus kas [11]. Metode ini juga memperhitungkan nilai waktu dari uang sehingga arus kas yang digunakan telah didiskontokan atas dasar biaya biaya modal/suku bunga/tingkat imbal hasil yang dibutuhkan. Berikut adalah rumus untuk menghitung IRR:

$N P V=0=\frac{C F_{1}}{(1+i)^{1}}+\frac{C F_{2}}{(1+i)^{2}}+\cdots \frac{C F_{n}}{(1+i)^{n}}-I_{o}$
$\mathrm{CF}_{1}, \mathrm{CF}_{2}, \mathrm{CF}_{\mathrm{n}}$ : arus kas dari tahun 1 hingga ke $\mathrm{n}$

$i$ : biaya modal/tingkat imbal hasil yang

dibutuhkan

$n \quad$ : umur investasi

$I_{O} \quad:$ investasi awal

\section{E. NPV dan IRR}

Pada penelitian sangat dimungkinkan terjadinya konflik antara nilai IRR dan NPV pada perbandingan nilai proyek dengan menggunakan pembiayaan syariah dan dengan menggunakan pembiayaan konvensional. Dalam memilih penentuan pendanaan yang dipilih memerlukan salah satu kriteria yang lebih dominan. Untuk memilih antara kedua alternatif perhitungan tersebut peneliti melakukan studi literatur mengenai hal tersebut. Berikut merupakan hasil penelitian mengenai pemilihan antara IRR dan NPV jika terjadi konflik:

1. Menurut [6] jika dalam suatu penentuan alternatif investasi pada proyek terjadi konflik antara IRR dan NPV maka penyelesaian dari konflik tersebut dengan berbasis pada nilai NPV atau MIRR dan mengabaikan nilai dari IRR

2. Dalam menentukan penggunaan NPV atau IRR perlu diperhatikan bentuk dari proyek investasi yang menjadi objek penelitian. Jika obyek penelitian adalah penilaian suatu proyek yang tanpa ada alternatif maka menggunakan IRR lebih diutamakan. Sedangakan jika menilai suatu alternatif proyek yang bersifat mutually exclusive maka NPV akan lebih baik digunakan [2].

3. Sejalan dengan penelitian kedua penelitian sebelumnya [4] mengungkapkan dalam penelitiannya bahwa jika terjadi konflik antara kedua metode, maka NPV lebih dipilih karena NPV lebih konsisten untuk memaksimalkan keuntungan dan metode NPV lebih mudah untuk diaplikasikan.

Dari hasil studi yang dilakukan, dalam penelitian ini jika terjadi konflik antara NPV dan IRR pada pemilihan pembiayaan syariah maupun pembiayaan konvensional, maka NPV akan lebih diprioritaskan untuk menjadi solusi konflik tersebut dan mengesampingkan nilai dari IRR.

\section{METODOLOGI PENELITIAN}

Ada 4 tahapan utama dalam penelitian ini, yaitu tahap pengumpulan data, tahap pengolahan data, tahap analisis dan pembahasan, serta tahap kesimpulan dan saran.

\section{A. Tahap Pengumpulan Data}

Pada tahapan ini penulis mengumpulkan data dari perancangan PLTU yang akan dibuat. Data dari perancangan PLTU didapatkan dari manajemen PT. X. Data yang dikumpulkan oleh penulis adalah berupa profil proyek obyek penelitian, struktur pendapatan proyek, struktur biaya proyek, sumber pembiayaan proyek dan data laporan keuangan perusahaan. Sedangkan data ekternal yaitu data yang berasal dari luar perusahaan yang diperlukan dalam melakukan justifikasi dan penentuan asumsi pada saat melakukan penelitian seperti kondisi perekonomian Indonesia dan regulasi yang berlaku. 


\section{B. Tahap Pengolahan Data}

Langkah selanjutnya yang dilakukan oleh penulis adalah pengolahan data. Pada tahap ini dimulai dengan pembuatan model finansial pada proyek pengembangan usaha. Setelah dilakukan pembuatan model finansial. Selanjutnya, menghitung nilai WACC pembiayaan syariah. Nilai WACC digunakan sebagai diskonto untuk melakukan penilaian proyek dengan menggunakan pendekatan pendapatan. Perhitungan pada proyek akan menghasilkan nilai dari proyek. Selanjutnya dilakukan perbandingan nilai antara pembiayaan syariah dengan pembiayaan konvensional.

\section{Tahap Analisis dan Pembahasan}

Tahap ini akan dilakukan interpretasi dan analisis mengenai nilai proyek yang didapatkan dari tahap pengolahan data dengan sumber pembiayaan yang berbeda beserta faktor-faktor yang mempengaruhi nilai tersebut. Selain itu dilakukan analisis sensitivitas pada faktor yang paling berpengaruh pada model pembiayaan syariah.

\section{Kesimpulan dan Saran}

Tahap ini merupakan tahapan paling terakhir dalam penelitian. Kesimpulan akan didapat dari hasil penelitian dan analisis yang telah dilakukan. Kesimpulan yang didapat diharapkan dapat menjawab tujuan dari penelitian yang telah ditetapkan sebelumnya Selain itu penulis juga memberikan saran yang berkaitan dengan pengembangan dari penelitian yang telah dilakukan.

\section{ANALISIS DATA DAN DISKUSI}

\section{A. Profil Perusahaan dan Proyek}

PT. X merupakan anak perusahaan dari PT. Y yang ditunjuk dan ditugaskan untuk menyelenggarakan usaha penyedia listrik utama untuk PT. Y, industri dan fasilitas usaha PT. Y, serta konsumen umum yang terdiri dari berbagai golongan mulai dari rumah tangga, perhotelan hingga kelompok industri yang berada di sekitar PT. X. Selain memberikan suplai listrik, PT. $\mathrm{X}$ juga melayani kebutuhan pelanggan yang menyangkut berbagai masalah kelistrikan. Mulai dari jasa operasi dan perawatan pembangkit listrik, jasa workshop, sewa alat berat, jasa kelistrikan, jasa konsultasi serta jasa pelabuhan untuk bongkar muat.

Pembangunan PLTU pertama PT. Y pada akhir tahun 70-an sebelum akhirnya unit PLTU tersebut menjadi usaha mandiri yaitu PT. X di akhir tahun 90'an. PT. X memiliki dua jenis pembangkit, yaitu CCPP (combined cycle power plant) yang memiliki daya sebesar $120 \mathrm{MW}$ dengan supply existing sebesar 102 MW dan PLTU (pembangkit listrik tenaga uap) yang memiliki daya $150 \mathrm{MW}$. Akan tetapi dengan adanya alasan bahan bakar gas alam yang tidak lagi ekonomis dan biaya maintenance tinggi, manajemen memutuskan untuk mengganti sumber bahan bakar pembangkit dengan tenaga batubara.

Dalam usaha meningkatkan kapasitas pasokan listrik PT. X memiliki rencana untuk membangun 2 unit PLTU dengan bahan bakar batubara yang memiliki kapasitas masing-masing sebesar 80 MWe. Proyek ini direncanakan dapat beroperasi pada tahun 2018 melalui proses kontruksi selama 2 tahun. Umur ekonomis dari PLTU selama 20 tahun. Proyek ini membutuhkan dana yang cukup banyak sehingga PT. X memerlukan dana dan pembiayaan dari luar perusahaan.

\section{B. Pembiayaan Syariah}

Model pembiayaan syariah IMBT yang digunakan adalah dengan mengasumsikan proyek diselesaikan selama 2 tahun dan disewakan selama 8 tahun dan kepemilikan PLTU diberikan kepada PT. X setelah masa sewa habis. Pembiayaan yang dapat didanai oleh bank syariah melalui IMBT sebesar USD 80,16 juta atau setara dengan Rp. 1,082 triliun (USD = Rp 13.500) meliputi kontruksi dan alat (EPC cost) PLTU. Dari data diatas selanjutnya melakukan perhitungan biaya sewa pembiayaan syariah. Berikut merupakan perhitungan harga sewa tiap tahun:

Biaya Sewa per tahun $=($ Margin Pembiayaan $\mathrm{x}$ Total Pembiayaan $)+($ Total Pembiayaan : Lama Sewa)

$$
\begin{aligned}
& =(12,16 \% \times 1,082 \text { triliun })+(1,082 \text { triliun : } 8) \\
& =131,5 \text { miliar }+135 \text { miliar } \\
& =266,5 \text { miliar }
\end{aligned}
$$

Biaya sewa yang dibayarkan oleh PT. X adalah margin pembiayaan sebesar $12,16 \%$ dari total biaya per tahun ditambah pokok pembiayaan tiap tahun sehingga pembayaran sewa yang dilakukan oleh PT. X tiap tahun adalah sebesar Rp 266,5 miliar. Selanjutnya membuat model valuasi dari proyek dengan terlebih dahulu menghitung nilai WACC. Sebelum menentukan WACC perlu dihitung terlebih dahulu cost of capital dari pembiayaan IMBT dengan (3) hingga didapatkan nilai cost of capital adalah $22,57 \%$. WACC pembiayaan syariah juga berbeda dengan WACC pada pembiayaan konvensional. Menggunakan (2) dihitung WACC pada pembiayaan syariah sehingga nilai dari WACC pembiayaan syariah adalah sebesar $21 \%$.

Nilai dari WACC akan digunakan sebagai faktor untuk mencari NPV dari proyek. Valuasi dari proyek didapatkan dari free cash flow proyek. Arus kas masuk dari pendapatan proyek dan arus kas keluar dari pengeluaran proyek. Hasil perhitungan free cash flow akan ditampilkan pada lampiran. Dengan mendiskontokan free cash flow tersebut dengan tingkat diskonto (WACC) sebesar $21 \%$ didapatkan nilai NPV proyek sebesar Rp 445.800.387.196,00 dan IRR sebesar 39,03\%

\section{Pembiayaan Konvensional}

Model pembiayaan konvensional sama seperti model-model pembiyaan pada umumnya. Total dana yang dibutuhkan dalam proyek ini adalah sebesar Rp. 1,343 $\mathrm{T}$ dan proporsi hutang sebesar $85 \%$ dari total kebutuhan proyek. Tingkat bunga yang digunakan adalah sebesar $11 \%$ dengan masa konstruksi selama 2 tahun dan pembayaran selama 8 tahun. Nilai WACC pada pembiayaan konvensional adalah sebesar $8,8 \%$. Nilai dari WACC akan digunakan sebagai faktor untuk mencari NPV dari proyek. Valuasi dari proyek didapatkan dari free cash flow proyek. Arus kas masuk dari pendapatan proyek dan arus kas keluar dari pengeluaran proyek. Hasil perhitungan free cash flow akan ditampilkan pada lampiran. Dengan mendiskontokan free cash flow tersebut dengan tingkat diskonto (WACC) sebesar 8,8\% didapatkan nilai NPV proyek sebesar Rp 


\subsection{8,00 dan IRR sebesar 16,64\%.}

\section{Perbandingan Pembiayaan}

Berdasarkan dari hasil valuasi, parameter dari nilai yang merepresentasikan dari proyek adalah NPV. Pembiayaan syariah memiliki nilai NPV sebesar Rp. 445 miliar. Ini berarti dari parameter perbandingan nilai proyek, pembiayaan syariah memiliki keuntungan secara financial lebih buruk dibanding dengan pembiayaan konvensional yang memiliki nilai sebesar Rp. 1,424 triliun. IRR sebagai informasi tambahan pada valuasi proyek, pembiayaan syariah memiliki IRR sebesar 39,03\% di mana ini lebih baik dibandingkan dengan pembiayaan konvensional yang memiliki IRR sebesar 16,64\%. Meskipun pembiayaan syariah memiliki nilai IRR yang lebih tinggi namun parameter utama dalam penilaian suatu proyek adalah NPV sehingga bisa dibilang bahwa pemilihan pembiayaan yang lebih baik adalah pembiayaan konvensional dari sisi penilaian.

\section{E. Analisis Sensitivitas}

Analisa sensitivitas adalah suatu analisis untuk dapat melihat pengaruh-pengaruh yang terjadi jika asumsi yang digunakan berubah-ubah. Pada penelitian ini analisis sensitivitas dilakukan pada model valuasi, yang mana dapat merubah ataupun tidak dari hasil penilaian proyek.

Nilai margin pembiayaan syariah adalah asumsi yang akan dilakukan percobaan. Terlebih lagi, margin pembiayaan syariah merupakan element yang akan berubah seiring berjalannya waktu dan dapat dinegosiasikan tingkat margin yang disepakati pada pembiayaan syariah dengan pihak pemberi pembiayaan IMBT. Berikut ini merupakan analisis sensitivitas dari perubahan pembiayaan syariah.

Dari hasil analisis di mana margin pembiayaan berubah secara berkala mulai berkurang $10 \%$ hingga bertambah $10 \%$, perubahan keputusan untuk menggunakan pembiayaan syariah adalah pada saat margin pembiayaan turun sebesar $9 \%$ dari margin asumsi. Hal ini karena nilai NPV dari proyek dengan menggunakan pembiayaan syariah adalah $\mathrm{Rp}$ 1,626 $\mathrm{T}$ lebih besar daripada nilai dari proyek dengan pembiayaan konvensional sebesar Rp. 1,424 T. Pada saat margin pembiayaan meningkat sebesar $9 \%$ merupakan batas untuk proyek layak untuk dilakukan karena pada saat margin pembiayaan meningkat sebesar $10 \%$ nilai dari NPV proyek menjadi negatif sehingga dapat dikatakan proyek tidak layak untuk dilanjutkan.

\section{KESIMPULAN/RINGKASAN}

Dari penelitian yang telah dilakukan didapatkan bahwa nilai NPV Proyek PLTU dengan pembiayaan syariah dihitung menggunakan pendekatan pendapatan adalah sebesar Rp. 445 miliar. Hal ini dapat diartikan bahwa proyek layak dijalankan dengan menggunakan pembiayaan syariah karena nilai NPV lebih dari nol.

Dari perbandingan pembiyaan syariah dan konvensional yang dilakukan. Nilai NPV Proyek PLTU dengan pembiayaan syariah adalah sebesar Rp. 445 miliar jauh lebih kecil dibandingkan dengan menggunakan pembiayaan konvensional yang memiliki nilai NPV sebesar Rp 1,424 T. Namun pembiayaan syariah memiliki IRR yang lebih besar yaitu $39,03 \%$ dibanding dengan pembiayaan konvensional dengan IRR sebesar 16,64\%. Pada penilaian dengan pendekatan pendapatan parameter utama yang digunakan adalah NPV sehingga pembiayaan konvensional lebih dipilih dibanding dengan pembiayaan syariah.

\section{LAMPIRAN}

Lampiran 1. Proyeksi pada Pembiayaan Syariah

\begin{tabular}{|c|c|c|c|c|c|c|}
\hline Year & Net Income & Investment & Depreciation & $\begin{array}{c}\text { Working } \\
\text { Capital }\end{array}$ & $\begin{array}{c}\text { Annual Cash } \\
\text { Flow }\end{array}$ & $\begin{array}{c}\text { Cumulative } \\
\text { Present Value }\end{array}$ \\
\hline 2015 & 0 & 0 & 0 & 0 & 0 & 0 \\
\hline 2016 & 0 & $(92.069 .090)$ & 0 & 0 & $(92.069 .090)$ & $(76.099 .905)$ \\
\hline 2017 & 0 & $(170.985 .453)$ & 0 & 0 & $(170.985 .453$ & $(192.915 .196)$ \\
\hline 2018 & 58.100 .022 & 0 & 0 & $(88.164 .783)$ & $(30.064 .762)$ & $(205.766 .614)$ \\
\hline 2019 & 81.527 .797 & 0 & 0 & $(2.680 .650)$ & 78.847 .146 & $(165.554 .731)$ \\
\hline 2020 & 107.533 .294 & 0 & 0 & $(2.922 .804)$ & 104.610 .490 & $(122.378 .263)$ \\
\hline 2021 & 132.943 .138 & 0 & 0 & $(2.863 .346)$ & 130.079 .792 & $(78.569 .115)$ \\
\hline 2022 & 160.784 .713 & 0 & 0 & $(3.136 .052)$ & 157.648 .661 & $(35.092 .311)$ \\
\hline 2023 & 132.236 .820 & 0 & 0 & 3.195 .734 & 135.432 .554 & $(3.996 .295)$ \\
\hline 2024 & 213.971 .697 & 0 & 0 & $(9.980 .179)$ & 203.991 .518 & 34.051 .342 \\
\hline 2025 & 264.762 .357 & 0 & 0 & $(4.899 .130)$ & 259.863 .227 & 73.815 .318 \\
\hline 2026 & 464.729 .298 & 0 & 56.001 .800 & $(3.912 .775)$ & 516.818 .324 & 137.393 .899 \\
\hline 2027 & 484.492 .140 & 0 & 56.001 .800 & $(2.244 .839)$ & 538.249 .102 & 192.124 .032 \\
\hline 2028 & 506.609 .502 & 0 & 56.001 .800 & $(2.509 .457)$ & 560.101 .845 & 239.197 .963 \\
\hline 2029 & 443.903 .082 & 0 & 56.001 .800 & 6.993 .454 & 506.898 .337 & 274.411 .090 \\
\hline 2030 & 541.806 .600 & 0 & 56.001 .800 & $(11.790 .654)$ & 586.017 .746 & 308.059 .516 \\
\hline 2031 & 578.788 .174 & 0 & 56.001 .800 & $(3.374 .844)$ & 631.415 .130 & 338.026 .238 \\
\hline 2032 & 604.270 .191 & 0 & 56.001 .800 & $(2.889 .516)$ & 657.382 .475 & 363.813 .940 \\
\hline 2033 & 626.566 .418 & 0 & 56.001 .800 & $(2.533 .824)$ & 680.034 .395 & 385.863 .284 \\
\hline 2034 & 651.516 .127 & 0 & 56.001 .800 & $(2.832 .091)$ & 704.685 .837 & 404.748 .876 \\
\hline 2035 & 573.269 .560 & 0 & 56.001 .800 & 8.718 .579 & 637.989 .939 & 418.881 .381 \\
\hline 2036 & 701.072 .218 & 0 & 56.001 .800 & $(15.133 .071)$ & 741.940 .947 & 432.465 .920 \\
\hline 2037 & 739.108 .755 & 0 & 56.001 .800 & 85.998 .788 & 881.109 .343 & 445.800 .387 \\
\hline & & & & & & \\
\hline
\end{tabular}

Lampiran 2. Proyeksi pada Pembiayaan Konvensional

\begin{tabular}{|c|c|c|c|c|c|c|}
\hline Year & Net Income & Investment & Depreciation & $\begin{array}{c}\text { Working } \\
\text { Capital }\end{array}$ & $\begin{array}{c}\text { Annual Cash } \\
\text { Flow }\end{array}$ & $\begin{array}{c}\text { Cumulative } \\
\text { Present Value }\end{array}$ \\
\hline 2015 & 0 & 0 & 0 & 0 & 0 & 0 \\
\hline 2016 & 0 & $(873.415 .475)$ & 0 & 0 & $(873.415 .475)$ & $(802.679 .357)$ \\
\hline 2017 & 0 & $(470.300 .640)$ & 0 & 0 & $(470.300 .640$ & $(1.199 .887 .363)$ \\
\hline 2018 & 9.451 .103 & 0 & 100.737 .822 & $(88.164 .783)$ & 22.024 .141 & $(1.182 .792 .618)$ \\
\hline 2019 & 30.373 .008 & 0 & 100.737 .822 & $(2.680 .650)$ & 128.430 .180 & $(1.091 .180 .708)$ \\
\hline 2020 & 53.596 .990 & 0 & 100.737 .822 & $(2.922 .804)$ & 151.412 .009 & $(991.922 .512)$ \\
\hline 2021 & 75.919 .353 & 0 & 100.737 .822 & $(2.863 .346)$ & 173.793 .829 & $(887.218 .910)$ \\
\hline 2022 & 100.333 .823 & 0 & 100.737 .822 & $(3.136 .052)$ & 197.935 .593 & $(777.628 .544)$ \\
\hline 2023 & 101.533 .860 & 0 & 56.001 .800 & 3.195 .734 & 160.731 .395 & $(695.844 .156)$ \\
\hline 2024 & 179.046 .202 & 0 & 56.001 .800 & $(9.980 .179)$ & 225.067 .823 & $(590.598 .468)$ \\
\hline 2025 & 226.860 .188 & 0 & 56.001 .800 & $(4.329 .016)$ & 278.532 .972 & $(473.840 .013)$ \\
\hline 2026 & 464.729 .298 & 0 & 56.001 .800 & $(4.482 .888)$ & 516.248 .210 & $(269.951 .910)$ \\
\hline 2027 & 484.492 .140 & 0 & 56.001 .800 & $(2.244 .839)$ & 538.249 .102 & $(74.590 .918)$ \\
\hline 2028 & 506.609 .502 & 0 & 56.001 .800 & $(2.509 .457)$ & 560.101 .845 & 112.237 .422 \\
\hline 2029 & 443.903 .082 & 0 & 56.001 .800 & 6.993 .454 & 506.898 .337 & 267.625 .547 \\
\hline 2030 & 541.806 .600 & 0 & 56.001 .800 & $(11.790 .654)$ & 586.017 .746 & 432.718 .654 \\
\hline 2031 & 578.788 .174 & 0 & 56.001 .800 & $(3.374 .844)$ & 631.415 .130 & 596.194 .792 \\
\hline 2032 & 604.270 .191 & 0 & 56.001 .800 & $(2.889 .516)$ & 657.382 .475 & 752.609 .907 \\
\hline 2033 & 626.566 .418 & 0 & 56.001 .800 & $(2.533 .824)$ & 680.034 .395 & 901.310 .495 \\
\hline 2034 & 651.516 .127 & 0 & 56.001 .800 & $(2.832 .091)$ & 704.685 .837 & 1.042 .922 .008 \\
\hline 2035 & 573.269 .560 & 0 & 56.001 .800 & 8.718 .579 & 637.989 .939 & 1.160 .747 .174 \\
\hline 2036 & 701.072 .218 & 0 & 56.001 .800 & $(15.133 .071)$ & 741.940 .947 & 1.286 .672 .992 \\
\hline 2037 & 739.108 .755 & 0 & 56.001 .800 & 85.998 .788 & 881.109 .343 & 1.424 .107 .712 \\
\hline & & & & & &
\end{tabular}

\section{UCAPAN TERIMA KASIH}

Penulis mengucapkan terima kasih kepada orang tua yang telah memberikan kesempatan untuk dapat menimba ilmu hingga jenjang ini dan juga atas bantuan yang telah mereka berikan baik moril maupun materil. Selain itu juga diucapkan terima kasih kepada kedua dosen Pembimbing yang telah membantu menyelesaikan penelitian ini hingga akhir. Terakhir kepada teman-teman yang selalu membantu dan juga pihakpihak lain yang membantu tanpa bisa disebutkan satu persatu. 


\section{DAFTAR PUSTAKA}

[1] Antonio, M. S. (2001). Bank Syariah dari Teori ke Praktik. Jakarta: Gema Insani Press.

[2] Arshad, A. (2012). Net Present Value is better than Internal Rate of Return. Interdisciplinary Journal of Contemporary Research in Business, 211-219.

[3] Asiyah, B. N. (2015). Manajemen Pembiayaan Bank Syariah. Yogyakarta: Kalimedia.

[4] Benerjee, S. (2015). Contravention between NPV \& IRR Due to Timing of Cash Flows: A Case of Capital Budgeting Decision of an Oil Refinery Company. American Journal of Theoretical and Applied Business, 48-52.

[5] Iqbal, Z. (1997). Islamic Financial Systems. World Bank Finance \& Development.

[6] Mackevicius, J., \& Tomasevic, V. (2010). Evaluation of Investment Projects in Case of Conflict between The Internal Rate of Return and The Net Present Value Methods. Ekonomika, 116-130.

[7] OJK. (2015). Laporan Statistik Perbankan Syariah. Jakarta: OJK.

[8] Prawoto, A. (2004). Penilaian Usaha. Yogyakarta: BPFE Yogyakarta.

[9] Ramadyanto, B. I. (2014). Memanfaatkan Dana Halal untuk Membiayai Pembangunan Infrastruktur di Indonesia.

[10] Sudana, I. M. (2009). Manajemen Keuangan. Surabaya: Airlangga University Press.

[11] Thuesen, G., \& Fabrycky, W. (2011). Engineering economy. New Jersey: Prentice Hall.

[12] Vogel, F. E., \& Hayes, S. L. (1998). Islamic Law and Finance: Religion, Risk, and Return. The Hague: Kluwer Law International.

[13] Wiroso. (2011). Akuntansi Transaksi Syariah. Jakarta: IAI. 